\title{
Distribution of heavy metals in edible bivalve Donax faba collected from Pasir Panjang: A health risk assessment
}

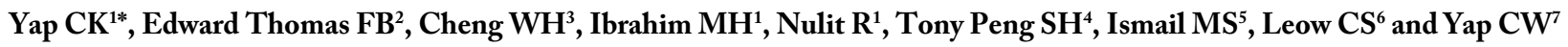 \\ ${ }^{1}$ Department of Biology, Faculty of Science, Universiti Putra Malaysia, 43400 UPM, Serdang, Selangor, Malaysia \\ ${ }^{2}$ Natural Resources and Environment Board, Petra Jaya, Kuching, Sarawak, Malaysia \\ ${ }^{3}$ Inti International University, Persiaran Perdana BBN, Nilai, Negeri Sembilan, Malaysia \\ ${ }^{4}$ All Cosmos Bio-Tech Holding Corporation, PLO650, Jalan Keluli, Pasir Gudang Industrial Estate, 81700 Pasir Gudang, Johor, Malaysia \\ ${ }^{5}$ Fisheries Research Institute, Batu Maung, 11960 Penang, Malaysia \\ ${ }^{6}$ Humanology Sdn Bhd, 73-3 Amber Business Plaza, Jalan Jelawat 1, 56000 Kuala Lumpur, Malaysia \\ ${ }^{7}$ Mes Solutions, 22C-1, Jalan BK 5A/2A, Bandar Kinrara, 47100 Puchong, Selangor, Malaysia
}

\begin{abstract}
The mudflat bivalve Donax faba, locally known as Lala, were collected from the intertidal area from Pasir Panjang, Negeri Sembilan, Malaysia. The collected bivalve were separated into five different tissue parts (remainder, muscle, foot, siphon, mantle, and gill) and together with their shells, were analyzed for the content of Cd, $\mathrm{Cu}, \mathrm{Ni}, \mathrm{Fe}, \mathrm{Pb}$ and $\mathrm{Zn}$. From this study, the $\mathrm{Cu}$ concentrations in the soft tissues of the bivalve are in the decreasing order of gills $>$ remainder $>$ mantle for all the three sampling sites. For $\mathrm{Zn}$, the highest concentrations of this metal were recorded in mantle and gill of the species. Non-essential metals, such as $\mathrm{Cd}$, $\mathrm{Pb}$, and $\mathrm{Ni}$ were found to be high accumulated in the shells. However, no clear pattern of Fe accumulation was observed in all the tissues in this study. For health risk assessment, all the Target Hazard Quotient (THQ) values for both Average Consumer (AC) and High Consumer (HC) for all six metals in this study were below one except for $\mathrm{Cd}$ for HC. Therefore, the bivalve found in Pasir Panjang is safe to be consumed as according to the THQ values (<1), but the consumption should be in moderation as the THQvalues were above one for Cd HC.
\end{abstract}

\section{Introduction}

An excessive amount of heavy metals content in global mangrove sediments has long been recorded, which is a devastating repercussion from anthropogenic activities [1-4]. Heavy metals are classified as one of the major pollutants threatening the well-being of the ecosystem due to their detrimental properties $[4,5]$. Due to rapid industrialization and urbanization, the coastal ecosystem, such as intertidal mangrove areas of tropical and subtropical countries, are susceptible to severe heavy metal pollution [6]. Human activities such as shipping, waste disposal are the leading cause of pollution in the mangrove ecosystem [7]. In addition to that, mangroves are well known for their ability to retain heavy metals owing to the anaerobic and sulphide-rich nature of the sediments $[1,6,8]$.

Thus, ongoing monitoring of heavy metals pollution should be conducted in mangrove areas as this ecosystem is not only the primary habitat for various flora and fauna but also serve as a seasonal shelter for migratory birds [7]. Apart from that, wetland ecosystems had been proven to be an effective mean of industrial, domestic and mining waste effluents treatment as the methods of treatments are simple and economical $[9,10]$.

Numerous reported studies had confirmed the feasibility of bivalve as good bio monitors for heavy metals in intertidal areas [1117] which is mainly due to the fact that the metal concentrations in the soft tissues of bivalves are able to give a clear profile of the heavy metals pollution status in the coastal waters $[15,16,18]$. Their sessile, relatively long life span and high tolerances of heavy metals enable them to display a time-integrated measurement of metals accumulation in a given environment. Therefore, their metal content is a direct reflection of the contamination history of the particular environment [19]. Since Donax faba is a common food among the locals, it is of utmost importance to assure that the safe consumption of this species. Cheng and Yap (2015) had reported the Target Hazard Quotient (THQ) of the mangrove snails, Nerita lineata, but the information on the safety consumption of $D$. faba in this region is scarce.

Heavy metals determination with statistical analysis of $D$. faba has been reported by [20] from samples collected in Pasir Panjang, but the actual values of the metal concentrations in the different tissues of the species were not presented. Thus, this study aims to present the concentrations of six metals in $D$. faba collected from Pasir Panjang in 2006 and to estimate the human health risk assessment of heavy metals from consuming the species.

\section{Materials and Methods}

\section{Preparation and metal extraction}

The bivalve D. faba (about 30 individuals) were collected from Pasir Panjang (Figure 1) on 28 April 2006. The samples were then dissected

${ }^{\star}$ Correspondence to: Yap CK, Department of Biology, Faculty of Science, Universiti Putra Malaysia, 43400 UPM, Serdang, Selangor, Malaysia, E-mail: yapckong@hotmail.com,yapchee@upm.edu.my

Key words: Different tissues, biomonitor, bivalves, heavy metals

Received: May 27, 2019; Accepted: June 17, 2019; Published: June 26, 2019 


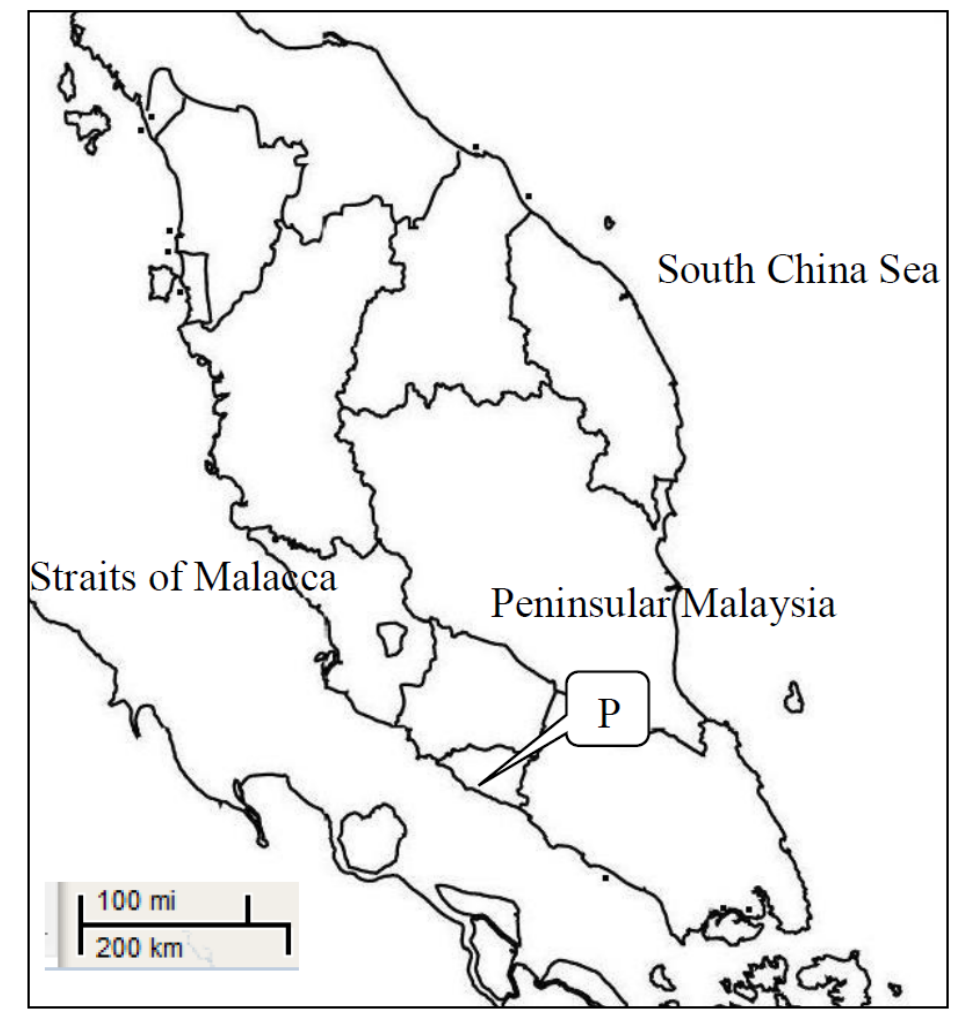

Figure 1. Map showing the sampling sites for Donax faba in Pasir Panjang (P), Peninsular Malaysia

into six different tissue parts: remainder, muscle, foot, siphon, mantle, and gill. All dissect tissues and shells were dried in the oven $\left(60^{\circ} \mathrm{C}\right)$ until the constant dry weight was obtained. Dried tissue parts were digested in concentrated $\mathrm{HNO}_{3}$ (Analar grade, $\mathrm{BDH} 69 \%$ ) by heating them in a hot-block digester. The acid-tissues mixture was first heated at $40^{\circ} \mathrm{C}$ for one hour ant then first at a low temperature for 1 hour, followed by full digestion at $140^{\circ} \mathrm{C}$ for at least 3 hours [21]. All tissues were prepared with triplicates. The digested sample was topped up with doubledistilled water (DDW) to a volume of $40 \mathrm{~mL}$ before filtration.

\section{Target Hazard Quotient}

Total Hazard Quotient values were determined from the formula below as proposed by [22] USEPA (2000). As the whole soft tissue data were not available in this study, the remainder tissue, which constituted the most significant portion of the total soft tissue of the species were chosen for THQ determination. The formula accounted for two groups of consumers depending on their degree of consumptions, namely Average Consumers (AC) and High Consumers (HC).

$\mathrm{THQ}=\mathrm{EDI} / \mathrm{ORD}-$

Where:

\section{$\mathrm{EDI}=(\mathrm{M} \times \mathrm{C} / \mathrm{BW})$}

$C=$ consumption rate consumption rate $(\mathrm{AC}=17.86$ and $\mathrm{HC}=$ $35.7 \mathrm{~g} / \mathrm{d}) ; M=$ concentration of metals of sample in this study $(\mathrm{mg} / \mathrm{kg}$ $\mathrm{ww}) ; \mathrm{B} W=$ average body weight of an adult $(60 \mathrm{~kg})$

The oral reference dose (ORD)was used in this study to evaluate the EDIs of metals in the bivalves. The ORD values $(\mu \mathrm{g} / \mathrm{kg} /$ day) used in this study were: $\mathrm{Cd}: 1.00$; $\mathrm{Cu}: 40.0$; $\mathrm{Ni}: 20.0$; Fe: 700; and $\mathrm{Zn}: 300$, provided by the USEPA's regional screening level [23].
Since $\mathrm{RfD}$ for $\mathrm{Pb}$ was not available according to the [23], the present study employed the ORD as $3.50 \mu \mathrm{g} / \mathrm{kg} /$ day as suggested by USEPA (2008).

Results with THQ value $>1$ indicate the possibility of health hazard based on a lifetime consumption of the metal-contaminated sample in the study [24].

\section{Metal determination}

Analysis of heavy metals was performed using the air-acetylene flame atomic absorption spectrophotometer (AAS) Perkin-Elmer Model Analyst 800, where data were presented in $\mu \mathrm{g} / \mathrm{g}$ dry weight. Quality of the analytical method was confirmed by conducting metal recovery analyses, and procedural blanks check. The data obtained from heavy metals recovery were of satisfaction (80-110\%) while procedural blanks and standard solutions for all six metals in this study were analyzed for every 5-10 samples to ensure accuracy of data.

\section{Results and Discussions}

Table 1 shows the condition index and allometric data of D. faba collected from Pasir Panjang. Based on Figures 2 and 3 and Table 2, it was observed that $\mathrm{Cu}$ was accumulated at higher concentrations in the gill and remainder as compared to other soft tissues. While the highest concentrations of $\mathrm{Zn}$ were detected in the gills and mantle, shells, on the other hand, accumulated the highest concentrations of $\mathrm{Cd}, \mathrm{Ni}$, and $\mathrm{Pb}$, which are the non-essential metals. High Fe concentrations were recorded in the muscle, gill, and mantle of the bivalve. According to [25] preposition on shellfishes, the distribution of metals in the tissues of $D$. faba could be explained based on three main factors. The first 


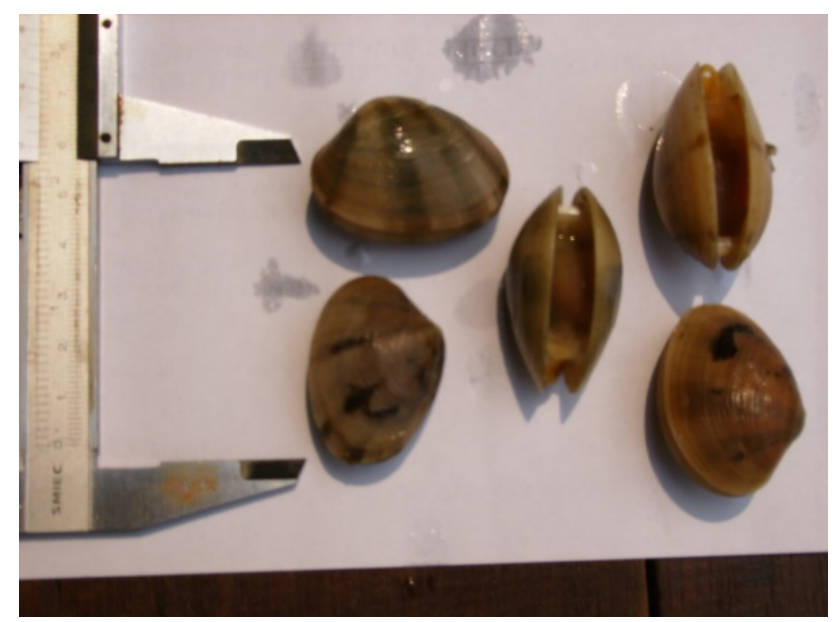

Figure 2. Donax faba collected from Pasir Panjang, Negeri Sembilan
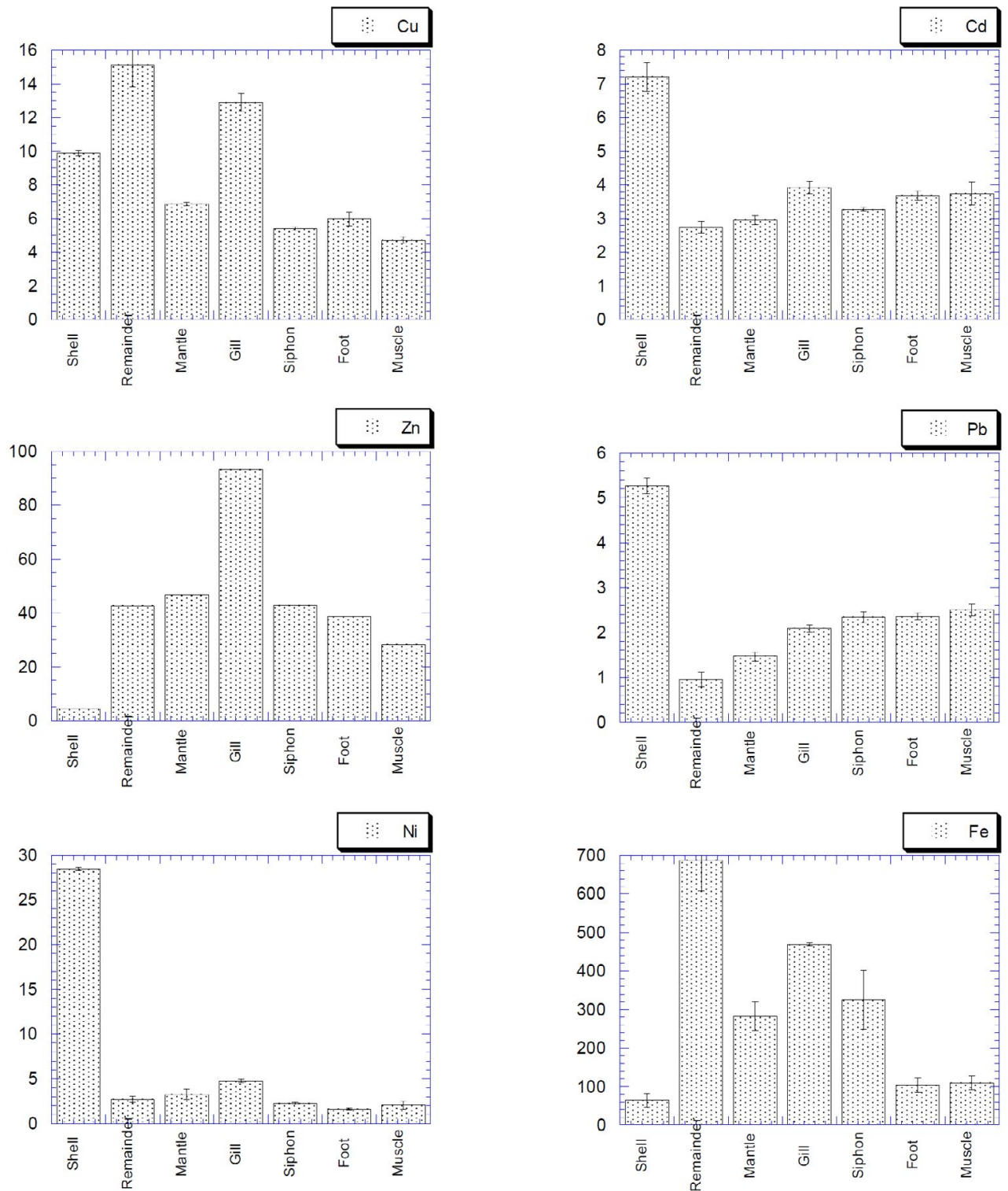

Figure 3. Heavy metal concentrations ( $\mathrm{Cu}, \mathrm{Cd}$. $\mathrm{Zn}, \mathrm{Pb}, \mathrm{Ni}$, and $\mathrm{Fe}$ ) in the different soft tissues of Donax faba (La-La) collected from Pasir Panjang, Negeri Sembilan 
Table 1. Mean values (mean \pm standard error) of condition index (CI) and other allometric parameters of Donax faba collected from Pasir Panjang

\begin{tabular}{|c|c|c|c|c|c|c|c|}
\hline Group & $\mathbf{N}$ & Shell lenght, (cm) & Shell width, $(\mathrm{cm})$ & Shell height, (cm) & $\begin{array}{l}\text { Soft tissue wet weight, } \\
\text { (g) }\end{array}$ & $\begin{array}{l}\text { Soft tissue dry weight, } \\
\text { (g) }\end{array}$ & CI (g/cm3) \\
\hline 1. & 10 & $\begin{array}{c}27.6-33.0 \\
(30.1 \pm 0.576)\end{array}$ & $\begin{array}{c}12.0-15.6 \\
(13.7 \pm 0.374)\end{array}$ & $\begin{array}{c}19.7-22.7 \\
(20.8 \pm 0.325)\end{array}$ & $\begin{array}{c}1.00-1.81 \\
(1.32 \pm 0.084)\end{array}$ & $\begin{array}{c}0.189-0.306 \\
(0.236 \pm 0.013)\end{array}$ & $\begin{array}{c}20.8-36.2 \\
(27.1 \pm 1.43)\end{array}$ \\
\hline 2. & 10 & $\begin{array}{c}40.8-45.6 \\
(42.5 \pm 0.409)\end{array}$ & $\begin{array}{c}20.2-24.8 \\
(22.4 \pm 0.429)\end{array}$ & $\begin{array}{c}28.7-34.5 \\
(31.3 \pm 0.663)\end{array}$ & $\begin{array}{c}2.68-6.05 \\
(3.77 \pm 0.314)\end{array}$ & $\begin{array}{c}0.572-1.13 \\
(0.753 \pm 0.054)\end{array}$ & $\begin{array}{c}22.1-29.0 \\
(25.0 \pm 0.842)\end{array}$ \\
\hline
\end{tabular}

Table 2. Ranges (and mean $\pm \mathrm{SE} \mu \mathrm{g} / \mathrm{g} \mathrm{dw}$ ) of heavy metal concentrations $(\mathrm{Cu}, \mathrm{Cd}, \mathrm{Zn}, \mathrm{Pb}, \mathrm{Ni}$, and $\mathrm{Fe}$ ) in the different part of tissues of Donax faba

\begin{tabular}{|c|c|c|c|c|c|c|}
\hline Tissues & $\mathbf{C u}$ & Cd & Zn & $\mathbf{P b}$ & $\mathbf{N i}$ & $\mathrm{Fe}$ \\
\hline Shell & $\begin{array}{c}9.73-10.0 \\
9.88 \pm 0.158\end{array}$ & $\begin{array}{c}6.77-7.63 \\
7.20 \pm 0.429\end{array}$ & $\begin{array}{c}4.55-4.57 \\
4.56 \pm 0.011\end{array}$ & $\begin{array}{c}5.10-5.43 \\
5.27 \pm 0.167\end{array}$ & $\begin{array}{c}28.3-28.7 \\
28.5 \pm 0.194\end{array}$ & $\begin{array}{l}47.0-81.1 \\
64.1 \pm 17.1\end{array}$ \\
\hline Remainder & $\begin{array}{c}13.8-16.4 \\
15.1 \pm 1.32\end{array}$ & $\begin{array}{c}2.57-2.91 \\
2.74 \pm 0.172\end{array}$ & $\begin{array}{c}42.2-43.1 \\
42.6 \pm 0.446\end{array}$ & $\begin{array}{c}0.790-1.12 \\
0.954 \pm 0.163\end{array}$ & $\begin{array}{c}2.37-3.03 \\
2.70 \pm 0.331\end{array}$ & $\begin{array}{c}608-767 \\
687 \pm 79.6\end{array}$ \\
\hline Mantle & $\begin{array}{c}6.76-6.97 \\
6.86 \pm 0.103\end{array}$ & $2.81-3.092 .95 \pm 0.139$ & $\begin{array}{l}44.6-49.1 \\
46.8 \pm 2.29\end{array}$ & $\begin{array}{c}1.37-1.56 \\
1.47 \pm 0.099\end{array}$ & $\begin{array}{c}2.66-3.83 \\
3.25 \pm 0.584\end{array}$ & $\begin{array}{c}244-320 \\
282 \pm 37.9\end{array}$ \\
\hline Gill & $\begin{array}{c}12.4-13.4 \\
12.9 \pm 0.536\end{array}$ & $\begin{array}{c}3.75-4.10 \\
3.92 \pm 0.175\end{array}$ & $\begin{array}{l}92.2-94.5 \\
93.4 \pm 1.16\end{array}$ & $\begin{array}{c}2.01-2.17 \\
2.09 \pm 0.079\end{array}$ & $\begin{array}{c}4.61-4.91 \\
4.76 \pm 0.149\end{array}$ & $\begin{array}{c}466-473 \\
470 \pm 3.81\end{array}$ \\
\hline Siphon & $\begin{array}{c}5.31-5.52 \\
5.41 \pm 0.103\end{array}$ & $\begin{array}{c}3.21-3.34 \\
3.28 \pm 0.066\end{array}$ & $\begin{array}{l}41.0-44.6 \\
42.8 \pm 1.84\end{array}$ & $\begin{array}{c}2.21-2.46 \\
2.34 \pm 0.121\end{array}$ & $\begin{array}{c}2.10-2.37 \\
2.24 \pm 0.135\end{array}$ & $\begin{array}{c}248-402 \\
325 \pm 77.3\end{array}$ \\
\hline Foot & $\begin{array}{c}5.58-6.37 \\
5.98 \pm 0.395\end{array}$ & $\begin{array}{c}3.54-3.83 \\
3.68 \pm 0.144\end{array}$ & $\begin{array}{c}38.1-39.4 \\
38.8 \pm 0.661\end{array}$ & $\begin{array}{c}2.28-2.43 \\
2.36 \pm 0.075\end{array}$ & $\begin{array}{c}1.49-1.67 \\
1.58 \pm 0.090\end{array}$ & $\begin{array}{l}85.3-123 \\
104 \pm 18.7\end{array}$ \\
\hline Muscle & $\begin{array}{c}4.51-4.92 \\
4.71 \pm 0.204\end{array}$ & $\begin{array}{c}3.39-4.08 \\
3.74 \pm 0.346\end{array}$ & $\begin{array}{c}27.5-29.1 \\
28.3 \pm 0.805\end{array}$ & $\begin{array}{c}2.38-2.63 \\
2.51 \pm 0.127\end{array}$ & $\begin{array}{c}1.59-2.47 \\
2.03 \pm 0.444\end{array}$ & $\begin{array}{l}91.7-127 \\
109 \pm 17.6\end{array}$ \\
\hline
\end{tabular}

Table 3. Target hazard quotient values of the six metals $(\mathrm{Cu}, \mathrm{Cd}, \mathrm{Zn}, \mathrm{Pb}, \mathrm{Ni}$ and $\mathrm{Fe})$ for $\mathrm{AC}$ and $\mathrm{HC}$ consuming the remainder tissues of Donax faba

\begin{tabular}{|c|c|c|c|c|c|}
\hline THQ values & Cu & Cd & Zn & Pb & Fe \\
\hline Average consumers (AC) & 0.11 & 0.82 & 0.04 & 0.08 & 0.04 \\
\hline High consumers (HC) & 0.22 & 1.63 & 0.08 & 0.16 \\
\hline
\end{tabular}

factor was attributed to the different surrounding contact area of each soft tissues differences in the surface of contact of the various soft tissues. The second factor involves the variation of affinities towards the binding site of metallothionein displayed by each metal in each tissue $[15,26,27]$. In this study, gill of $D$. faba has the highest concentration of $\mathrm{Cu}$ and therefore could have the highest affinity towards the metal. The last factor revolves around the accumulation and excretion rate of the metals differing in each soft tissue. Different rates of accumulation and depuration is an implication of metal treatment and regulation by the biological system of the species [28]. This is supported by different variation of metal concentrations found in the different tissues of $D$. faba in this study. Donax faba, like many other mollusks $[15,16,29,30]$, can provide the contamination status and integrated bioavailability of metals in coastal waters excelling over seawater and sediments as biomonitoring agents [31]. All the THQ values for both AC and HC for all six metals in this study were below one except for Cd for HC (Table 3). These values had indicated that there was no likelihood of adverse health effects for all the six metals from consumption of the remaining tissues of D. faba for AC and HC, except for Cd of HC. The results of safety consumption are somewhat in agreement with those reported by [32] for the same metals in this study but in N. lineata.

\section{Conclusion}

From the present study, D. faba exhibited its potential as a good biomonitoring agent where different parts of the species are could be a reflection of the metals contamination at a particular. It was shown that the species could exhibit the bioavailability of $\mathrm{Zn}$ in its gills, $\mathrm{Cu}$ and $\mathrm{Fe}$ in the remainder tissues and the non-essential metals (Cd, Ni, and $\mathrm{Pb}$ ) in the shells, from the surrounding of Pasir Panjang. The elevated concentrations of the six metals in the samples collected from Pasir Panjang denoted the high bioavailabilities these metals in the area. The species found in this site are safe to be eaten as according to the THQ values $(<1)$, but the consumption should be in moderation as the THQ values were above one for $\mathrm{HC}$.

\section{Acknowledgment}

The authors wish to acknowledge the financial support provided through the Research University Grant Scheme (RUGS) [Vote no: 91229] by the Universiti Putra Malaysia and e-Science Fund [Vote no: 5450338] by the Ministry of Science, Technology and Innovation, Malaysia.

\section{References}

1. Lacerda LD, Rezende CE, Argagon GT, Ovalle AR (1991) Iron and chromium transport and accumulation in a mangrove ecosystem. Water Air Soil Pollut 57: 513-520.

2. Perdomo L, Ensminger I, Espinos LF, Elsters C, Wallner-Kersanach M, et al. (1998) The Mangrove ecosystem of the Cienaga Grande de Santa Marta (Colombia): Observations on regeneration and trace metals in sediment. Mar. Pollut. Bull 37: 393-403.

3. Tam NFY, Wong YS (2000) Spatial variation of heavy metals in surface sediments of Hong Kong mangrove swamps. Environ. Pollut 110: 195-205. [Crossref]

4. Defew LH, Mair JM, Guzman HM (2005) An assessment of metal contamination in mangrove sediments and leaves from Punta Mala Bay, Pacific Panama. Mar. Pollut Bull 50: 547-552. [Crossref]

5. MacFarlane GR and Burchett (2002) Toxicity, growth and accumulation relationships of copper, lead and zinc in the grey mangrove Avicennia marina (Forsk.) Veirh. Mar Environ Res 54: 65-84. [Crossref]

6. Tam NFY and Yao MWY (1998) Normalisation and heavy metal contamination in mangrove sediments. The Sci Tot Environ 216: 33-39.

7. Dang TC, Bayen S, Wurl O, Subramaniam K, Kae SW, et al. (2005) Heavy metal contamination in mangrove habitats of Singapore. Mar. Pollut Bull 50: 1713-1744. [Crossref]

8. Thompson MF and Tirmizi NM (1995) Mangrove soil: Its mineralogy and texture. In: Ibrabim, N., Mubammed MJ, Sagbir A, editor. The Arabian Sea: Living marine resources and environment. Rotterdam: A.A. Balkema. pp. 431-439.

9. Harbison P (1986) Mangrove muds-a sink and a source for trace metals. Mar. Pollut Bull 17: 246-250. 
10. Conley LM, Dick RI, Lion LW (1991) An assessment of the root zone method of wastewater treatment. Res. J. Wat Pollut Cont Fed 63: 239-247.

11. Hamed MA and Emara AM (2006) Marine molluscs as Bio monitors for heavy meta levels in the Gulf of Suez, Red Sea. J. Mar Sys 60: 220-234.

12. Usero J, Morillo J, Gracia I (2005) Heavy metal concentrations in molluscs from the Atlantic coast of southern Spain. Chemosphere 59: 1175-1181. [Crossref]

13. Conti ME, Cecchetti G (2003) A biomonitoring study: trace metals in algae and molluscs from Tyrrhenian coastal areas. Environ Res. 93: 99-112. [Crossref]

14. Mubiana VK, Blust R (2000) Uptake of heavy metals in isolated gills of the marine bivalve Mytilus edulis. Comp. Biochem. Physiol 126: 108.

15. Yap CK, Ismail A, Cheng WH, Tan SG (2006a) Crystalline style and tissue redistribution in Perna viridis as indicators of $\mathrm{Cu}$ and $\mathrm{Pb}$ bio availabilities and contamination in coastal waters. Ecotox. Environ. Safety 63: 413-423. [Crossref]

16. Yap CK, Ismail A, Edward FB, Tan SG, Siraj SS (2006b) Use of different soft tissues pf Perna viridis as biomonitors of bioavailability and contamination by heavy metals $(\mathrm{Cd}$, $\mathrm{Cu}, \mathrm{Fe}, \mathrm{Pb}, \mathrm{Ni}$ and $\mathrm{Zn}$ ) in a semi-enclosed intertidal water, the Johore Straits. Toxicol Environ. Chem 88: 683-695.

17. Yap CK, Cheng WH, Karami A, Ismail A (2016) Health risk assessments of heavy metal exposure via consumption of marine mussels collected from anthropogenic sites. Sci. Tot. Environ 553: 285-296. [Crossref]

18. Nelson WG, Bergen BJ, Cobb DJ (1995) Comparisons of PCB and trace meta bioaccumulation in the blue mussel, Mytilus edulis, and the ribbed mussel, Modiolus demissus, in New Bedford Harbour, Massachusetts. Environ. Toxicol. Chem 14: 513-521.

19. Phillips DJH (1977) The use of biological indicator organisms to monitor trace metal pollution and estuarine environments - A review. Environ. Pollut 13: 281-316.

20. Yap CK, Edward FB, Tan SG (2010) Similarities and differences of metal distributions in the tissues of molluses by using multivariate analyses. Environmental Monitoring and Assessment 165: 39-53. [Crossref]

21. Yap CK, Ismail A, Tan SG (2003a) Background concentrations of $\mathrm{Cd}, \mathrm{Cu}, \mathrm{Pb}$ and $\mathrm{Zn}$ in the green-lipped mussel Perna viridis (Linnaeus) from Peninsular Malaysia. Mar. Pollut. Bull 46: 1035-1048. [Crossref]
22. USEPA (US Environmental Protection Agency) (2000) Guidance for assessing chemical contaminant data for use in fish advisories. Vol. 1: Fish sampling and analysis. 3rd Edition. U.S. Environmental Protection Agency, EPA-823-B-00-007, Washington, DC, 2000.

23. USEPA (US Environmental Protection Agency) (2015) Human health risk assessment. Regional screening level (RSL) - USEPA (US Environmental Protection Agency) 2008. USEPA, Integrated Risk Information System. CRC.

24. Bogdanovic T, Ujevic I, Sedak M, Listes E, Simat V, et al. (2014) As, Cd, Hg and Pb in four edible shellfish species from breeding and harvesting areas along the eastern Adriatic Coast, Croatia. Food Chem 146: 197-203. [Crossref]

25. Yap CK, Ismail A, Omar H, Tan SG (2003b) Accumulation, depuration and distribution of cadmium and zinc in the green-lipped mussel Perna viridis (Linnaeus) under laboratory conditions. Hydrobiologia 498: 151-160.

26. Roesijadi G (1980) The significance of low molecular weight, metallothionein-like protein in marine invertebrates: Current status. Mar. Environ. Res. 4: 167-179.

27. Viarengo A, Palmero S, Zanicchi G, Capelli R, Vaissiere R, et al. (1985) Role of metallothioneins in $\mathrm{Cu}$ and $\mathrm{Cd}$ accumulation and elimination in the gill and digestive gland cells of Mytilus galloprovincialis (Lam.). Mar. Environ. Res. 16: 23-36.

28. Gundacker C (1999) Tissues-specific heavy metal $(\mathrm{Cd}, \mathrm{Pb}, \mathrm{Cu}, \mathrm{Zn})$ deposition in a natural population of the zebra mussel Dreissena polymorpha Pallas. Chemosphere 38: 3339-3356. [Crossref]

29. Rainbow PS (1995) Biomonitoring of heavy metal availability in the marine environment. Mar. Pollut. Bull 31: 183-192.

30. Rainbow PS, Smith BD, Lau SS (2002) Biomonitoring of trace metal availabilities in the Thames estuary using a suite of littoral biomonitors. J. Mar. Biol. Asso 82: 793-799.

31. Phillips DJH, Rainbow PS (1993) Biomonitoring of trace aquatic contaminants, 2nd ed London: Chapman and Hall.

32. Cheng WH, Yap CK (2015) Potential human health risks from toxic metals via mangrove snail consumption and their ecological risk assessments in the habitat sediment from Peninsular Malaysia. Chemosphere 135: 156-65. [Crossref]

Copyright: (2019 Yap CK. This is an open-access article distributed under the terms of the Creative Commons Attribution License, which permits unrestricted use, distribution, and reproduction in any medium, provided the original author and source are credited. 